\title{
COMPARATIVE STUDY ON ANTIMICROBIAL ACTIVITY OF SEAWEEDS
}

\author{
SASIKALA C*, GEETHA RAMANI D \\ Department of Microbiology, Dr. N. G. P. Arts and Science College, Coimbatore, Tamil Nadu, India. \\ Email: sasikalac@drngpasc.ac.in
}

Received: 28 June 2017, Revised and Accepted: 13 September 2017

\section{ABSTRACT}

Objective: Secondary metabolites from natural resources are a potential source of antimicrobial leads and drugs can exploited to combat antimicrobial resistance in microorganisms. Seaweeds are considered as a valuable source with a broad spectrum of biological activities. Hence, this study was undertaken to screen seaweeds from Mandapam coastal waters, East coast of India, for antimicrobial activity.

Methods: Compounds were extracted using methanol from the seaweeds, namely, Halimeda gracilis, Caulerpa serrulata, Sargassum swartzii, Sargassum wightii, Jania rubens, Ulva lactuca, Ulva fasciata, Gracilaria corticata, Stoechospermum marginatum, Caulerpa scalpelliformis, Caulerpa taxifolia, Chaetomorpha crassa, Enteromorpha flexuosa, and Turbinaria ornate. The extracts were screened for their antimicrobial activity against selected bacterial and fungal pathogens.

Results: In the present study, $S$. swartzii, J. rubens, and $S$. marginatum showed broad spectrum of antibacterial activity against all the test bacterial pathogens. Among these, the maximum activity was exhibited by S. swartzii against Enterococcus faecalis (27.00 \pm 0.88 ) and Streptococcus pyogenes $(23.00 \pm 0.84)$, followed by J. rubens against E. faecalis $(26.00 \pm 0.56)$ and $S$. pyogenes $(22.00 \pm 0.75)$, and $S$. marginatum exhibited significant inhibition against Staphylococcus aureus (15.00 \pm 0.22$)$ and S. pyogenes $(18.00 \pm 1.16)$.

Conclusion: These seaweeds with significant antibacterial activity will subjected to phytochemical screening to find out the potential active principle responsible for antimicrobial activity. It is followed by purification and characterization of the compounds for possible application in drug formulation, can take this to large-scale application in pharmaceutical industries.

Keywords: Seaweeds, Methanol, Antimicrobial, Secondary metabolites, Sargassum swartzii, Stoechospermum marginatum, Jania rubens, Enterococcus faecalis.

(C) 2017 The Authors. Published by Innovare Academic Sciences Pvt Ltd. This is an open access article under the CC BY license (http://creativecommons. org/licenses/by/4. 0/) DOI: http://dx.doi.org/10.22159/ajpcr.2017.v10i12.21002

\section{INTRODUCTION}

Seaweeds or marine algae are primitive nonflowering plants without true root stem and leaves [1]. They are the renewable living sources of food, feed, and fertilizer in many parts of the world. They have been screened extensively to isolate life-saving drugs or biologically active substances worldwide. There are numerous reports of macroalgae derived secondary metabolites with diverse activities. Marine sources are receiving much attention mainly because of the contents of functional ingredients such as polyunsaturated acids, $\beta$-carotene and their pigment carotenoids, sulfated polysaccharide, and sterol [2]. Different parts of the thalli are also known to differ in their antimicrobial potential. The levels of antimicrobial activities of marine algae have shown geographical variation. However, information is lacking on the geographic variations in the specific metabolites of marine algae with potential antimicrobial activity, especially the marine algae in South India. The coastal region of Tamil Nadu, South India, produces a rich vegetation of marine algae [3]. The Gulf of Mannar situated along the East Coast of India and Sri Lanka, possesses abundant growth of about 680 species of seaweed [4].

As infectious diseases are a major cause of morbidity and mortality worldwide, systematic exploration of these marine seaweeds would give valuable antimicrobial lead compounds and drugs which can be exploited commercially as pharmaceutical industries also recognize the compounds derived from natural resources [5].

\section{METHODS}

\section{Collection of samples}

The samples of Halimeda gracilis, Caulerpa serrulata, Sargassum swartzii, Sargassum wightii, Jania rubens, Ulva lactuca, Ulva fasciata, Gracilaria corticata, Stoechospermum marginatum, Caulerpa scalpelliformis, Caulerpa taxifolia, Chaetomorpha crassa, Enteromorpha flexuosa, and Turbinaria ornate were collected by handpicking at Mandapam coastal waters, East coast of India (Pudumadam - Lat 9 ${ }^{\circ} 16^{\prime} \mathrm{N}$; Long $78^{\circ} 69^{\prime} \mathrm{E}$, Nochiyrani - Lat $9^{\circ} 16^{\prime} \mathrm{N}$; Long $79^{\circ} 1.94^{\prime} \mathrm{E}$, Thonithurai - Lat $9^{\circ} 16^{\prime} \mathrm{N}^{\prime}$ Long $79^{\circ} 11.3^{\prime} \mathrm{E}$ ). The collected samples were cleaned well with seawater to remove all the extraneous matter such as epiphytes, sand particles, pebbles, and shells and brought to the laboratory in plastic bags. The samples were then thoroughly washed with freshwater, blotted, and spread out at room temperature for drying. Shade-dried samples were grounded to fine powder [1]. The powdered samples were then stored in the refrigerator for further use.

\section{Herbarium preparation}

For the morphological identification of the collected seaweeds, the whole part of the fresh seaweeds was placed between the multiple layers of filter paper and bundled tightly until complete dryness to avoid fungal contamination. The filter paper was changed with the interval of every 3 days. The seaweeds were then removed and pasted on chart paper $(24 \mathrm{~cm} \times 43 \mathrm{~cm})$ using gum.

\section{Identification of seaweeds}

The seaweeds were identified and authenticated by Dr. V. Veeragurunathan, Scientist, Marine Algal Research Station, Central Salt and Marine Research Institute, Mandapam Camp, Ramanathapuram, Tamil Nadu, India.

\section{Preparation of extracts}

The dried seaweed materials were blended into a coarse powder. Portions of the powdered samples (5 g) were packed in Soxhlet apparatus and extracted with methanol for 10 hrs. The extract was 
collected and concentrated under vacuum on a rotary evaporator at low temperature to get crude methanolic extracts. The crude extracts thus obtained were refrigerated until experimentation.

\section{Microbial strains}

Bacterial strains used for assay were as following: Escherichia coli, Klebsiella pneumoniae, Staphylococcus aureus, Salmonella typhi, Streptococcus pyogenes, Enterococcus faecalis, Pseudomonas aeruginosa, Bacillus subtilis, and Proteus vulgaris. While fungal strains were Aspergillus niger, Candida albicans, Penicillium sp., Cryptococcus neoformans, and Trichophyton sp., microbial strains were obtained from Bioline laboratories, Coimbatore, and Kovai Medical Center and Hospitals, Coimbatore, and identified according to standard procedure (Bergey's Manual, Fungal identification Manual)

\section{Antimicrobial assay}

The antimicrobial assay was carried out by the standard disc diffusion method [6]. Sterile discs of $6 \mathrm{~mm}$ in diameter were used. $24 \mathrm{hrs}$ broth cultures of test strain were loaded on a sterile cotton swab that was rotated several times and press firmly against the inside wall of the tube to remove excess inoculum from the swab. The Petri plates were poured with $20 \mathrm{ml}$ of Muller-Hinton Agar. The dried surface of an agar plate was inoculated by streaking the swab over the entire sterile agar surface. This procedure was repeated two more times, rotating the plate approximately $60^{\circ} \mathrm{C}$ each time to ensure a uniform distribution of inoculums [7]. Then, the plates were allowed to dry for 5 minutes. After drying the extract impregnated, discs were placed on the plate with the help of sterilized forceps and gently pressed to ensure contact with the media. The plates were incubated at $37^{\circ} \mathrm{C}$ and $28^{\circ} \mathrm{C}$, respectively, for bacteria ( $24 \mathrm{hrs}$ ) and fungi ( $48 \mathrm{hrs}$ ). After incubation, the diameter of the zone of inhibition was measured using a scale and quantified in mm

\section{RESULTS}

\section{Identification of seaweeds}

The seaweeds collected for the study were identified and listed in Table 1.

\section{Antimicrobial assay}

Among the seaweeds subjected to screening, S. swartzii, J. rubens, and $S$. marginatum showed broad range of inhibition against most of the tested pathogens. The maximum activity was observed against $E$. faecalis $(27.00 \pm 0.88)$ and $S$. pyogenes $(22.00 \pm 0.75)$. The antimicrobial activity expressed as the diameter of the zone of inhibition in mm is tabulated (Tables 2 and 3).

Table 1: Identification of seaweeds collected from Mandapam coast

\begin{tabular}{|c|c|c|c|c|c|c|}
\hline S. No. & Name of the seaweeds & Type* & Class & Subclass & Order & Family \\
\hline 1 & H. gracilis & $\mathrm{G}$ & Chlorophyceae & Ulvophyceae & Bryopsidales & Halimedaceae \\
\hline 2 & C. serrulata & $\mathrm{G}$ & Chlorophyceae & Ulvophyceae & Bryopsidales & Caulerpaceae \\
\hline 3 & S. swartzii & $\mathrm{B}$ & Phaeophyceae & Fucophycidae & Fucales & Sargassaceae \\
\hline 4 & S. wightii & $\mathrm{B}$ & Phaeophyceae & Fucophycidae & Fucales & Sargassaceae \\
\hline 5 & J. rubens & $\mathrm{R}$ & Florideophyceae & Corallinophycidae & Corallinales & Corallinaceae \\
\hline 6 & U. lactuca & $\mathrm{G}$ & Chlorophyceae & Ulvophyceae & Ulvales & Ulvaceae \\
\hline 7 & U. fasciata & $\mathrm{G}$ & Chlorophyceae & Ulvophyceae & Ulvales & Ulvaceae \\
\hline 9 & S. marginatum & $\mathrm{B}$ & Phaeophyceae & Dictyotophycidae & Dictyotales & Dictyotaceae \\
\hline 10 & C. scalpelliformis & $\mathrm{G}$ & Chlorophyceae & Ulvophyceae & Bryopsidales & Caulerpaceae \\
\hline 11 & C. taxifolia & $\mathrm{G}$ & Chlorophyceae & Ulvophyceae & Bryopsidales & Caulerpaceae \\
\hline 12 & C. crassa & $\mathrm{G}$ & Chlorophyceae & Ulvophyceae & Cladophorales & Cladophoraceae \\
\hline 13 & E. flexuosa & $\mathrm{G}$ & Chlorophyceae & Ulvophyceae & Ulvales & Ulvaceae \\
\hline 14 & T. ornate & B & Phaeophyceae & Fucophycidae & Fucales & Sargassaceae \\
\hline
\end{tabular}

*G: Green algae, B: Blue algae, R: Red algae, H. gracilis: Halimeda gracilis, C. serrulata: Caulerpa serrulata, S. swartzii: Sargassum swartzii, S. wightii: Sargassum wightii, J. rubens: Jania rubens, U. lactuca: Ulva lactuca, U. fasciata: Ulva fasciata, G. corticata: Gracilaria corticata, S. marginatum: Stoechospermum marginatum, C. scalpelliformis: Caulerpa scalpelliformis, C. taxifolia: Caulerpa taxifolia, C. crassa: Chaetomorpha crassa, E. flexuosa: Enteromorpha flexuosa, T. ornate: Turbinaria ornate

Table 2: The antibacterial activity of seaweeds tested against the bacterial pathogens

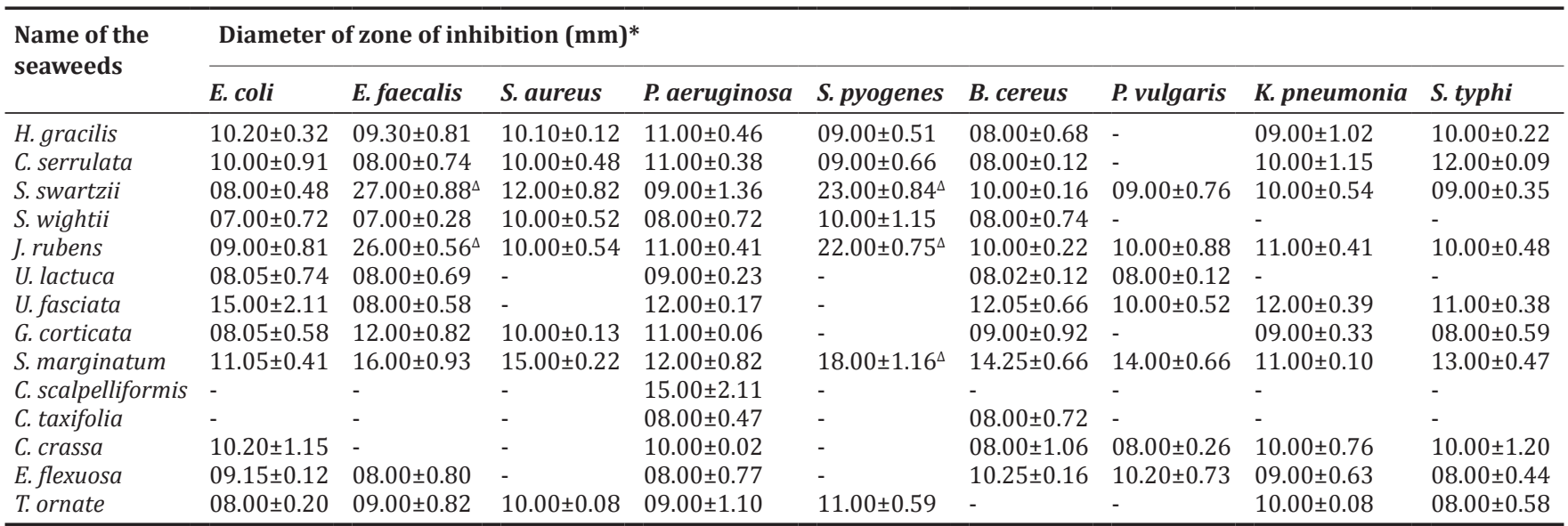

${ }^{*}$ The value indicates the standard error mean of experiments done in triplicates. ${ }^{\star}$ Maximum inhibition. H. gracilis: Halimeda gracilis,

C. serrulata: Caulerpa serrulata, S. swartzii: Sargassum swartzii, S. wightii: Sargassum wightii, J. rubens: Jania rubens, U. lactuca: Ulva lactuca,

U. fasciata: Ulva fasciata, G. corticata: Gracilaria corticata, S. marginatum: Stoechospermum marginatum, C. scalpelliformis: Caulerpa scalpelliformis,

C. taxifolia: Caulerpa taxifolia, C. crassa: Chaetomorpha crassa, E. flexuosa: Enteromorpha flexuosa, T. ornate: Turbinaria ornate, E. coli: Escherichia

coli, E. faecalis: Enterococcus faecalis, S. aureus: Staphylococcus aureus, P. aeruginosa: Pseudomonas aeruginosa, S. pyogenes: Streptococcus pyogenes,

B. cereus: Bacillus subtilis, P. vulgaris: Proteus vulgaris, K. pneumonia: Klebsiella pneumoniae, S. typhi: Salmonella typhi 
Table 3: Antifungal activity of seaweeds tested against fungal pathogens

\begin{tabular}{|c|c|c|c|c|c|}
\hline \multirow[t]{2}{*}{ Name of the Seaweeds } & \multicolumn{5}{|c|}{ Diameter of zone of inhibition (mm)* } \\
\hline & C. albicans & C. neoformans & A. niger & P. crysogenum & T. rubrum \\
\hline H. gracilis & $08.00 \pm 0.22$ & - & - & - & $09.00 \pm 0.17$ \\
\hline C. serrulata & $08.00 \pm 0.09$ & - & - & - & $08.00 \pm 0.22$ \\
\hline S. swartzii & - & $20.00 \pm 1.56^{\Delta}$ & - & - & - \\
\hline S. wightii & - & $10.00 \pm 0.02$ & - & - & - \\
\hline J. rubens & - & $08.00 \pm 0.29$ & - & - & - \\
\hline U. lactuca & - & - & - & - & $09.00 \pm 0.51$ \\
\hline U. fasciata & $09.00 \pm 0.82$ & - & - & - & $11.00 \pm 0.49$ \\
\hline G. corticata & $08.00 \pm 0.47$ & - & - & - & $08.00 \pm 0.09$ \\
\hline S. marginatum & - & - & - & - & $06.00 \pm 0.06$ \\
\hline C. scalpelliformis & - & - & - & - & - \\
\hline C. taxifolia & - & - & - & - & - \\
\hline C. crassa & $08.00 \pm 0.61$ & - & - & - & $09.00 \pm 0.58$ \\
\hline E. flexuosa & - & - & - & - & $08.00 \pm 0.37$ \\
\hline T. ornate & - & - & - & - & $10.00 \pm 0.33$ \\
\hline
\end{tabular}

\section{DISCUSSION}

Antimicrobial activity of red, brown, and green algae against both bacteria and fungi has been recognized by several scientists, and some reported that the species of Rhodophyta and Phaeophyta exhibited a diverse range of antibacterial activity. In the present study, both the species of Phaeophyta and Rhodophyta showed the strongest activities against the tested bacteria, which were in agreement with the findings of Padmakumar and Ayyakannu [8]. The in vitro antimicrobial activity of seaweeds extracted with methanol, ethanol, and acetone was reported in various studies $[9,10]$. However, the strong antimicrobial activity was reported using methanol [11-13]. Previous studies reported that the antibacterial compounds are more active against Gram-positive bacteria than Gram-negative bacteria. The resistance of Gram-negative bacteria toward antibacterial substances is related to the hydrophilic surface of their outer membrane which is rich in lipopolysaccharide molecules, presenting a barrier to the penetration of numerous antibiotic molecules. The membrane is also associated with the enzymes in the periplasmic space which is capable of breaking down the molecules introduced from outside [14]. However, the Gram-positive bacteria do not possess such outer membrane and cell wall structures [15]. The best antibacterial was recorded with Gracilaria edulis, Sargassum swartzii, J. rubens, Enteromorpha flexuosa, G. Corticata, C. Scalpelliformis, C. taxifolia, and Ulva fasciata. The present study proved that the methanolic extract of $S$. marginatum showed good activity against all the tested bacterial species. It exhibited the highest activity against $S$. pyogenes $(18.00 \pm 1.16)$ and moderate activity against $E$. coli $(11.05 \pm 0.41)$ and Klebsiella pneumonia $(11.00 \pm 0.10)$. It also accounts the maximum activity of Enteromorpha flexuosa against Bacillus cereus $(10.25 \pm 0.16)$ and moderate activity against $P$. vulgaris (10.20 \pm 0.73 ). The present study Caulerpa taxifolia showed inhibition against $P$. aeruginosa $(08.00 \pm 0.47)$ and Bacillus cereus $(08.00 \pm 0.72)$.

\section{CONCLUSION}

Further work is in progress which aimed at the investigation of detailed phytochemical screening of seaweeds to find the potential of natural secondary metabolites. Furthermore, detailed studies on quantification, purification, and evaluation of such compounds can take this to a large scale application in pharmaceutical industries.

\section{REFERENCES}

1. Ashwinikumar P, Soundarapandian P, Jagan K, Anatharaman P, Kannan D, Sanjeev Kumar, et al. Associate Fauna in cultured seaweed
Kappaphycus alvarezii of Vellar Estuary (South East Coast of India). Int J Res Mar Sci 2014;3 Suppl 2:37-43.

2. Radhika D, Veerabahu C, Priya A. Antibacterial activity of some selected seaweeds from the Gulf of Mannar coast, South India. Asian J Pharmaceut Clin Res 2012;5 Suppl 4:89-90.

3. Manivannan K, Devi GK, Anantharaman P, Balasubramanian T. Antimicrobial potential of selected brown seaweeds from Vedalai coastal waters, Gulf of Mannar. Asian Pac J Trop Biomed 2011;1(2):114-20

4. Devi KP, Suganthy N, Kesika P, Pandian SK. Bioprotective properties of seaweeds: In vitro evaluation of antioxidant activity and antimicrobial activity against food borne bacteria in relation to polyphenolic content. BMC Complement Altern Med 2008;8:38.

5. McGee P. Natural Products re-emerge. Drug Dis Dev 2006;9:18-26.

6. Bauer AW, Kirby WM, Sherris JC, Turck M. Antibiotic susceptibility testing by a standardized single disk method. Am J Clin Pathol 1966;45(4):493-6.

7. Scorzoni L, Benaducei T, Almeida AM, Silva BH, Bolzani VS, MendesGiannini MJ. Comparative study of disk diffusion and micro dilution methods for evaluation of antifungal activity of natural compounds against medical yeasts Candida spp. J Basic Appl Pharmaceut Sci 2007;28:25-34.

8. Padmakumar K, Ayyakannu K. Seasonal variation of antibacterial and antifungal activities of the extracts of marine algae from southern Coast of India. Botanica Mar 1997;40:507-15.

9. Shan B, Cai YZ, Brooks JD, Corke H. The in vitro antibacterial activity of dietary spice and medicinal herb extracts. Int J Food Microbiol 2007;117(1):112-9.

10. Seenivasan R, Indu $H$, Archana G, Geetha $S$. The antibacterial activity of some marine algae from south east coast of India. Am Eurasian J Agric Environ Sci 2010;9 Suppl 5:480-9.

11. Priyadarshini S, Bragadeeswaran S, Prabha K, Rani SS. Antimicrobial and hemolytic activity of seaweed extracts of Ulva fasciata from Mandapam, South East Coast of India. Asian Pac J Trop Biomed 2012;1(2):38-9.

12. Khadija O, Nabila B, Samira E, Omar A. Anti-inflammatory activities of twenty-three marine red algae from the coast of Sidi Bouzid (EL Jadida - Morocco). Int J Pharm Pharm Sci 2013;5 Suppl 3:145-9.

13. Lamia M, Kamel C, Abderrahman B. Evaluation of antimicrobial activity of organic practions of six marine algae from tunisian mediterranean coasts. Int J Pharm Pharm Sci 2012;4 Suppl 1:534-7.

14. Kim IH, Lee JH. Antimicrobial activities against methicillin resistant Staphylococcus aureus from macroalgae. J Indian Eng Chem 2008; 14:568-72.

15. Kalemba D, Kunicka A. Antibacterial and antifungal properties of essential oils. Curr Med Chem 2003;10(10):813-29. 